\title{
ATTRACTING FOREIGN DIRECT INVESTMENT IN TRANSITION ECONOMIES WITH SPECIAL REFERENCE TO THE REPUBLIC OF MACEDONIA
}

\author{
MSc Marija Gogova Samonikov, Teaching assistant, Faculty of Economics, \\ Department of finance, "Goce Delcev" University, Stip, Macedonia, \\ e-mail: marija.gogova@ugd.edu.mk, + 38932550310 \\ MSc Elena Veselinova, Teaching assistant, Faculty of Economics, \\ Department of management, "Goce Delcev" University, Stip, Macedonia, \\ e-mail: elena.veselinova@ugd.edu.mk, phone: + 38932550314
}

\begin{abstract}
The focus of this paper is an analysis of foreign direct investment and their impact and scale in countries in transition, with special reference to Macedonia.

The main aim of this article is to show the investment in Macedonia, in the period before and after the crisis of 2007 and to provide guidance for future activities that will help improve the economic situation in general.

The results show that the Macedonian economy is especially supported by active government action on this issue. Government and its activities significantly improve the position of Macedonia in relation to neighboring countries, but there are still areas that need to act. Such domain infrastructure is an issue that would fulfill the image of Macedonian policy for attracting foreign investors.

The conclusion is that despite all activities there are determinants that affect traditional markets. The most important of them is the level of gross domestic product. Macedonia has taken many measures to increase the level of GDP and in the level of attracting foreign capital has introduced tax benefits, customs benefits and other benefits with which is competitive with neighboring countries. However, GDP and employment are still not satisfactorily reflected.
\end{abstract}

Key words: foreign direct investment, attracting foreign direct investment, government activities.

\section{Introduction by defining the concept and characteristics of the term foreign direct investment in the Republic of Macedonia and their importance to the economy}

Direct investment are form of capital transactions and investments by an investor who intends to establish economic relations and / or acquire the right to manage the company or other legal entity in which he invested. The direct investments include the establishment of a company fully owned by the developer; increasing the capital of the company fully owned by the developer; branching; acquisition of full ownership of an existing company; participation in new or already existing trading company owning more than $10 \%$ of right for decision making; long-term loan with maturity of five years or more, when it comes as loan from the investor intended for trading company in its wholly owned; long-term loan with maturity of five years or more, when it comes to loan intended for establishment of economic relations and if given between economic connected stakeholders.

Countries in transition and developing countries, especially the Macedonian economy often highlight the foreign direct investment as a solution to improve the economic situation. Macedonian expertise suggests a solution in increasing the production capacity of the country. Right here are spot foreign direct investments as a catalyst to better economic activity. Not only production, but also the financial market in Macedonia shows need for revival and from that point not only the private sector but also the government implemented (or are trying to implement) activities that will attract investment in the country as Macedonia.

Empirical research of Finndlay at the end of the 1970s, pointed out that the contribution of foreign direct investment (FDI) to economic growth goes through "diffusion of 
knowledge" of domestic firms with more advanced technology and better management practices, and Blomstorm and Kokko with example of the 78 developing countries concluded that technological progress and knowledge transfer are mechanisms through which foreign direct investment stimulate economic development (Gruevski, 2007). However we should consider possibility of a negative impact, if foreign investment bid domestic entity with what makes danger domestic entity to be knocked out of the market. Studies show that the positive impact of foreign investment on employment and foreign trade is more pronounced in export-oriented countries. If prevailing complementarily of FDI and exports, foreign direct investment will cause an increase in employment and favorable external condition - trade balance. If there is substitution of foreign direct investment and exports, employment in the export sector make place of employment in the sector of the economy receiving country. (Nenovska, 2012).

\section{Conditions of foreign direct investments in Republic of Macedonia in period before and after 2007}

Macedonia can be attractive for foreign investors, but with well thought out policy and effective policy. That is because FDI in Macedonia are influenced by global economic trends, which is normally Fact is that exist advantages in terms of countries that surround Macedonia which makes politics for attracting FDI, and in this case we exclude them.

Tables below show the situation in Macedonia at level of: relation between production, financial activities, the Balkan countries and the level of GDP.

Figure 1: Rate of participation of FDI in GDP of countries in transition, 1990-2010, in\%

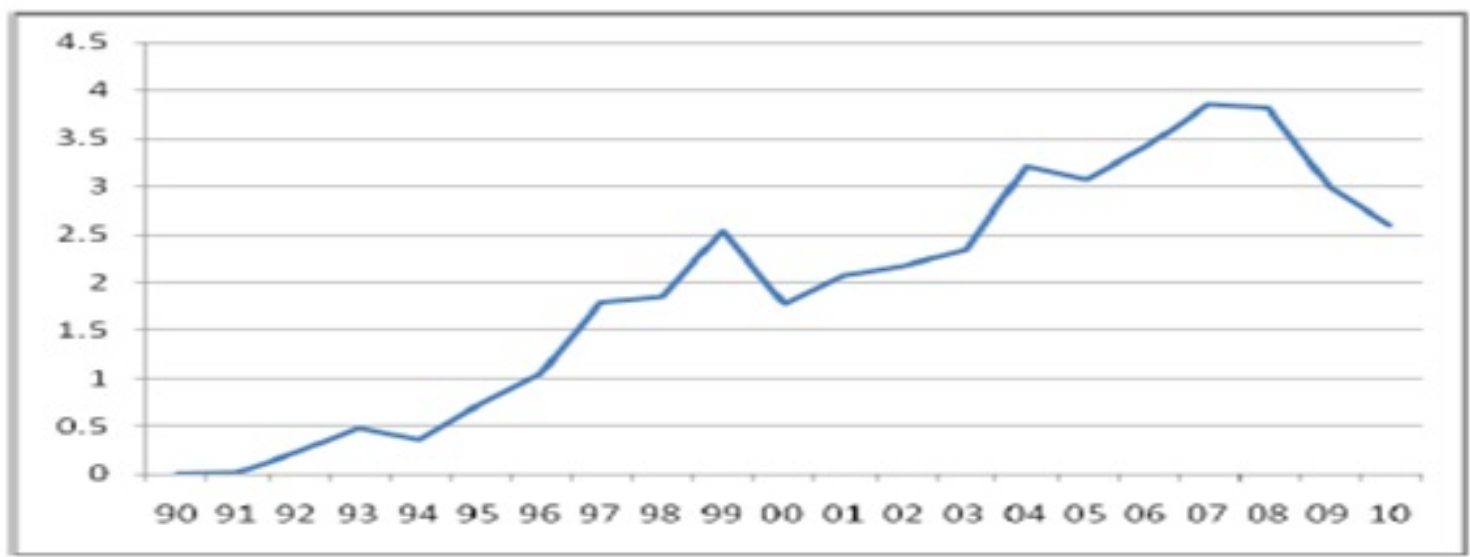

Source: UnctadStat (2011) 
Figure 2: Growth rate of FDI in transition countries, 1993-2010, in \%

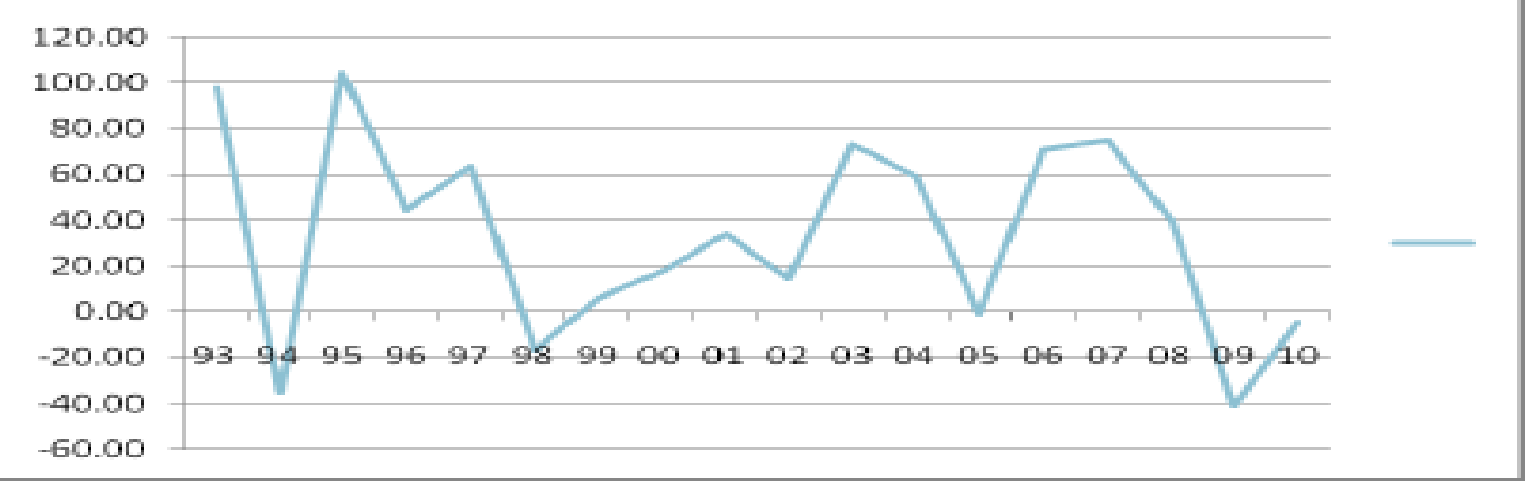

Source: UnctadStat (2011), World investment report 2011

Graph data show that regardless of whether the share of FDI in GDP or perceived investment growth trend over the years after 2007 it declining. Peak is achieved just before the global economic crisis of 2007, and after that the investment is reduced and reactivates again about 2010. But this is far slower reactivating and investments occupy a much smaller growth rate. Below are the data of the situation in Republic of Macedonia. Table 1 shows the level of foreign direct investment in manufacturing. Production is considered in this paper as an important component, often alarmed as the most significant element for Macedonian economy.

\section{Table 1: Foreign direct investments in Republic Macedonia in the field of manufacturing (period 2006-2012)}

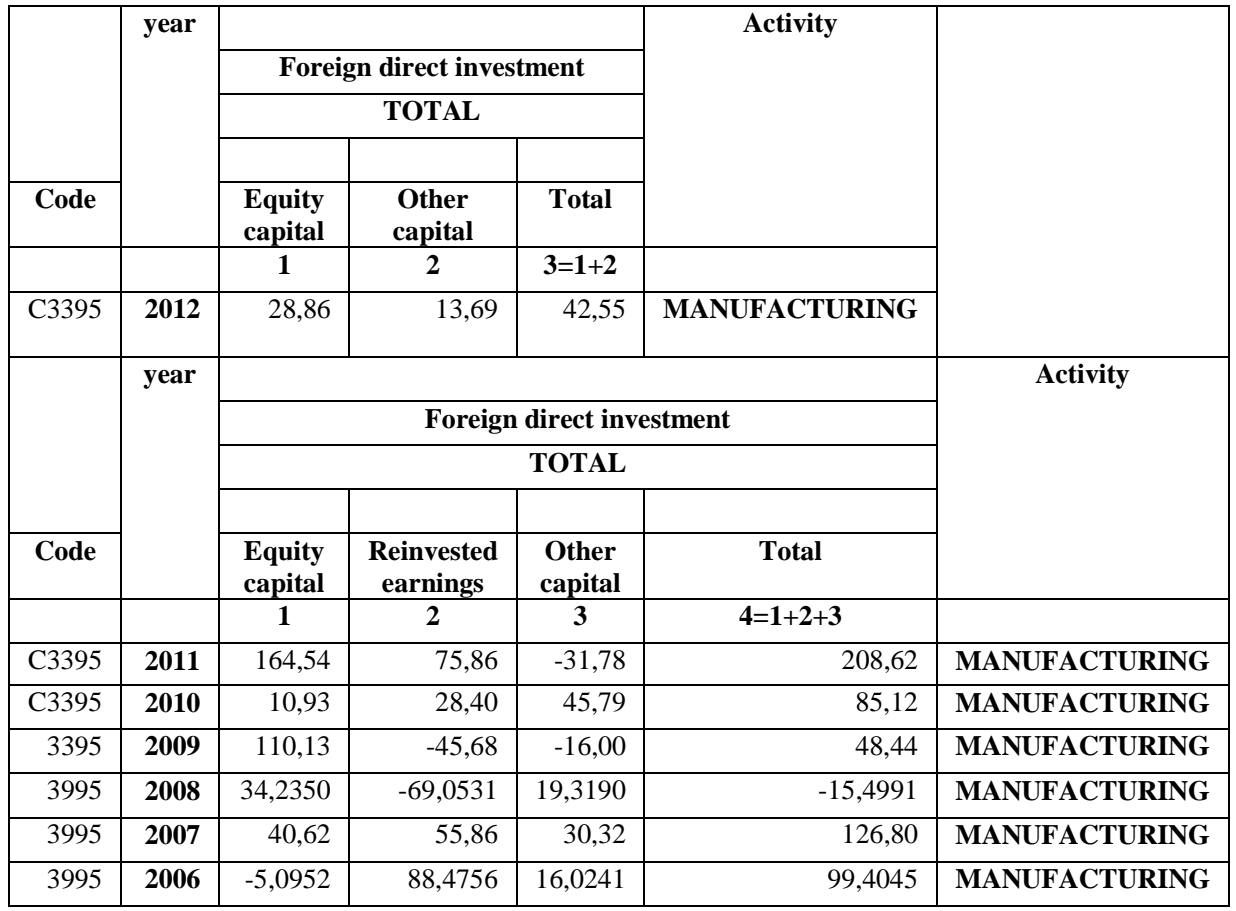

Source: Adapted from data of the National Bank of the Republic of Macedonia 
Table 2 and 3 show the level of investment in Macedonia in the field of financial performance and overall image of direct investments realized in 2006 2012. Specifically it should be noted about this analysis is that because of the recording of data in the National Bank of Macedonia cumulative result of financial activities before 2008 not exist and this area apart from the production has a negative trend after the crisis and its reactivating begins in 2011. In the plan of foreign direct investment 2012 is not shown as successful. Downward trend is followed in manufacturing and in the total investment. In the level of financial insurance activities is observed occurrence of minus balance.

Table 2: Foreign direct investments in Republic Macedonia in the field of financial and insurance activities (period 2008-2012)

\begin{tabular}{|c|c|c|c|c|c|c|}
\hline \multirow{4}{*}{$\begin{array}{l}\text { Code } \\
\text { Con }\end{array}$} & \multirow[t]{4}{*}{ year } & & & & \multirow[t]{4}{*}{ Activity } & \\
\hline & & \multicolumn{3}{|c|}{ Foreign direct investment } & & \\
\hline & & \multicolumn{3}{|c|}{ TOTAL } & & \\
\hline & & $\begin{array}{l}\text { Equity } \\
\text { capital }\end{array}$ & $\begin{array}{l}\text { Other } \\
\text { capital }\end{array}$ & Total & & \\
\hline & & 1 & 2 & $3=1+2$ & & \\
\hline \multirow[t]{4}{*}{ K6695 } & 2012 & 28,79 & $-44,45$ & $-15,67$ & $\begin{array}{l}\text { FINANCIAL AND } \\
\text { INSURANCE } \\
\text { ACTIVITIES }\end{array}$ & \\
\hline & \multirow[t]{4}{*}{ year } & & & & & \multirow[t]{4}{*}{ Activity } \\
\hline & & \multicolumn{4}{|c|}{ Foreign direct investment } & \\
\hline & & \multicolumn{4}{|c|}{ TOTAL } & \\
\hline \multirow[t]{2}{*}{ Code } & & $\begin{array}{l}\text { Equity } \\
\text { capital }\end{array}$ & $\begin{array}{c}\text { Reinvested } \\
\text { earnings }\end{array}$ & $\begin{array}{c}\text { Other } \\
\text { capital }\end{array}$ & Total & \\
\hline & & 1 & 2 & 3 & $4=1+2+3$ & \\
\hline K6695 & 2011 & 68,00 & $-3,65$ & 3,27 & 67,62 & $\begin{array}{l}\text { FINANCIAL AND } \\
\text { INSURANCE } \\
\text { ACTIVITIES }\end{array}$ \\
\hline K6695 & 2010 & 29,12 & $-5,48$ & $-48,18$ & $-24,54$ & $\begin{array}{l}\text { FINANCIAL AND } \\
\text { INSURANCE } \\
\text { ACTIVITIES }\end{array}$ \\
\hline 6695 & 2009 & 28,42 & $-50,22$ & 12,90 & $-8,90$ & $\begin{array}{l}\text { FINANCIAL AND } \\
\text { INSURANCE } \\
\text { ACTIVITIES }\end{array}$ \\
\hline 6695 & 2008 & & & & NO DATA AS 6695 & $\begin{array}{l}\text { FINANCIAL AND } \\
\text { INSURANCE } \\
\text { ACTIVITIES }\end{array}$ \\
\hline
\end{tabular}

Source: Adapted from data of the National Bank of the Republic of Macedonia 
Table 3: Total foreign direct investments in Republic Macedonia (period 2006-2012)

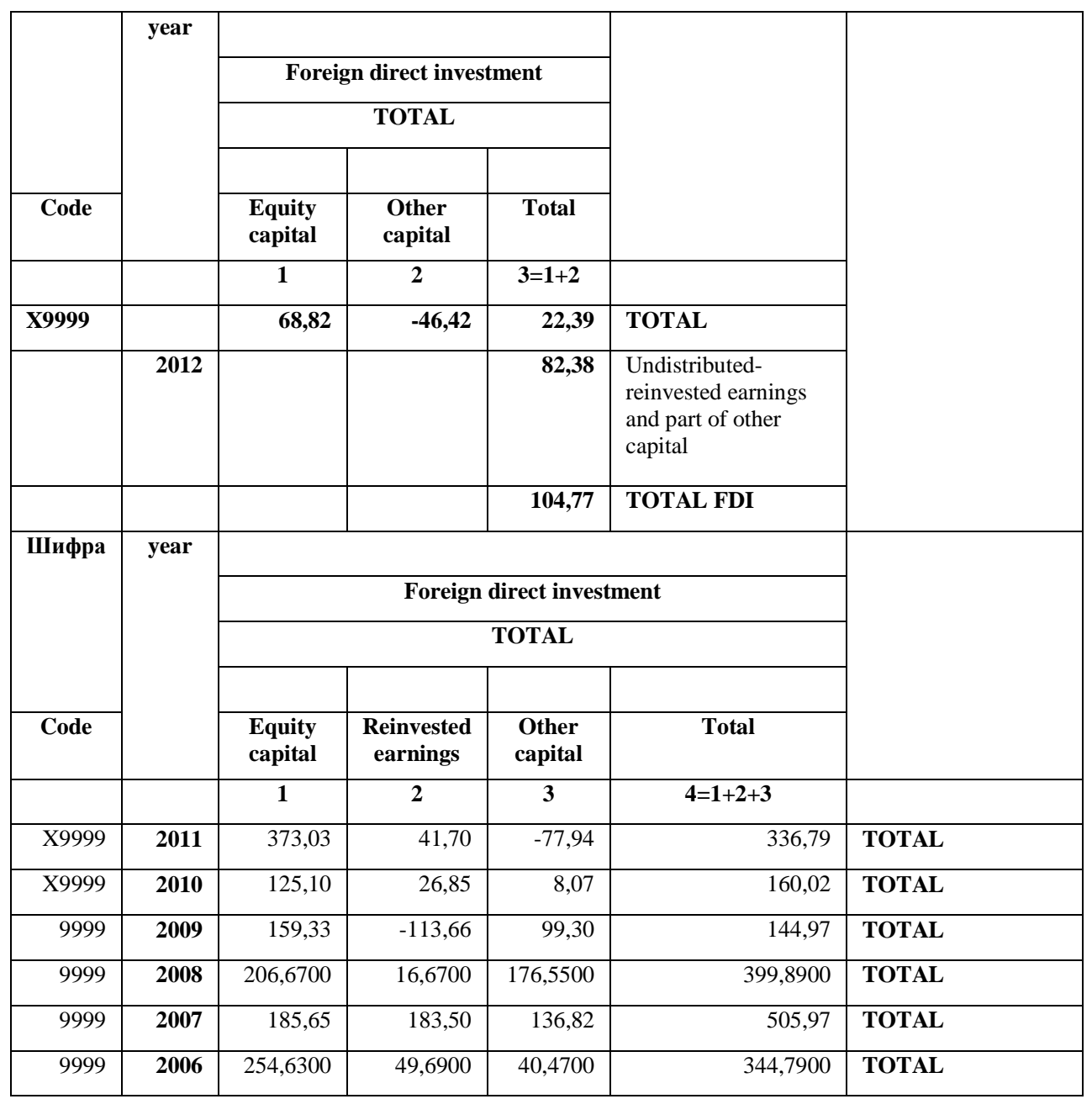

Source: Adapted from data of the National Bank of the Republic of Macedonia

The level of the Balkan region data are shown in Table 4 and 5. The data show that Albania, Croatia, Montenegro and Slovenia decreased investment in, 2012. Out of them the relationship is most evident in Slovenia. Bulgaria, Bosnia and Serbia are the countries that recorded growth in 20112012, but it must be noted that Serbia is still in minus balance. 
Table 4: Foreign direct investments in Republic of Macedonia - FLOWS - by country for 2012

\begin{tabular}{|c|c|c|c|c|}
\hline \multirow[b]{2}{*}{ Code } & \multirow[t]{2}{*}{$\begin{array}{l}\text { Preliminary data } \\
\text { in mill. EUR }\end{array}$} & \multirow[b]{2}{*}{$\begin{array}{l}\text { Equity } \\
\text { capital }\end{array}$} & \multirow[b]{2}{*}{$\begin{array}{l}\text { Other } \\
\text { capital }\end{array}$} & \multirow[b]{2}{*}{ Total } \\
\hline & & & & \\
\hline 0008 & ALBANIA & 0,17 & 0,32 & 0,49 \\
\hline 0070 & BOSNIA AND HERZEGOVINA & 0,00 & 0,39 & 0,39 \\
\hline 0100 & BULGARIA & 2,39 & 1,78 & 4,17 \\
\hline 0191 & CROATIA & 3,70 & $-1,20$ & 2,49 \\
\hline 0499 & MONTENEGRO & $-0,29$ & $-0,67$ & $-0,96$ \\
\hline 0688 & SERBIA & $-1,16$ & 0,37 & $-0,79$ \\
\hline 0705 & SLOVENIA & 0,81 & $-33,41$ & $-32,60$ \\
\hline
\end{tabular}

Source: Adapted from data of the National Bank of the Republic of Macedonia

Table 5: Foreign direct investments in Republic of Macedonia - FLOWS - by country for 2011

01.01.2011 - 31.12.2011

Preliminary data

in mill. EUR

\begin{tabular}{|c|c|c|c|c|c|}
\hline & Country & & & & \\
\hline & & & oreign direc & nvestmen & \\
\hline Code & & $\begin{array}{l}\text { Equity } \\
\text { capital }\end{array}$ & $\begin{array}{l}\text { Reinvested } \\
\text { earnings }\end{array}$ & $\begin{array}{c}\text { Other } \\
\text { capital }\end{array}$ & Total \\
\hline & & 1 & 2 & 3 & $4=1+2+3$ \\
\hline 008 & ALBANIA & 6,00 & 1,99 & $-2,69$ & 5,30 \\
\hline 070 & BOSNIA AND HERZEGOVINA & 0,18 & 0,04 & $-0,01$ & 0,21 \\
\hline 100 & BULGARIA & $-8,70$ & $-0,16$ & 12,71 & 3,85 \\
\hline 191 & CROATIA & 0,50 & 1,86 & 5,72 & 8,08 \\
\hline 499 & MONTENEGRO & $-0,05$ & 0,04 & 0,67 & 0,66 \\
\hline 688 & SERBIA & 1,02 & $-0,67$ & $-5,47$ & $-5,12$ \\
\hline 705 & SLOVENIA & 95,61 & $-25,13$ & $-58,65$ & 11,83 \\
\hline
\end{tabular}

Source: Adapted from data of the National Bank of the Republic of Macedonia 


\section{Activities that Macedonian economy has taken to encourage foreign direct investment}

Macedonian government takes many activities specifically about attracting foreign investors. This field is one of the primary government actions to revive the economy. Lacking sufficient domestic resources for starting and developing domestic production, government bodies are actively working and are directed at attracting foreign capital. In the Constitution of Macedonia all investors are guaranteed with national treatment. Foreign investors are protected from political risk, and receive tax benefits, customs benefits and advantages in the TIRZ (technology development industrial zones). Allowed 100\% foreign-owned capital, there is no restriction on repatriation of profits, investors can purchase land Subject Company to be registered in Macedonia, establish a one-stop shop and a separate office in the IRS for large taxpayers. Finally is formed Agency for Foreign Investments of the Republic of Macedonia. Tax benefits are in the VAT and in personal income tax.

Concluding observations for guidance Macedonian activities in attracting foreign direct investment

According Mateev determinants of FDI in traditions are divided into two groups, the first of which are traditional determinants related to: market size, distance to market, the cost of trade costs related to the jobsite, the relative proportion of factors of production. The second factor is non-traditional and concern: the share of private businesses in the overall economy, the type of privatization carried out in the country, the quality of infrastructure, corruption and the risk associated with each country - host. The same author points out that the market size is measured by GDP, the larger the GDP greater attractiveness of country - host. As additional determinants that are important for increasing the attractiveness of the country to attract investment are openness to the global economy, the value of the domestic currency, EU and tax breaks.
Macedonia is constantly making efforts to attract foreign capital. There are undertaken and taken many measures that significantly simplify the position of investors, but despite that, the period to 2012 the level of investment moves below 10\% (excluding production). The biggest investment Macedonian economy has seen in Austria, Greece, Switzerland, Slovenia. However in 2012 due to the European economic situation turned bad year for this field. Regardless of this, the Macedonian government should engage around infrastructure. Infrastructure issue arises as a unresolved to complete the picture of determinants that are necessary to attract foreign investors. Here we have to mention that all the time we write about nontraditional Mateevs' determinants. From traditional determinants GDP is the most important variable which must be operated independently to foreign investment. GDP is important not only for attracting FDI, but because of the aspect that it is a basic indicator of the health of the economy.

\section{References:}

9. Mishkin F., (2004) The Economics of Money, Banking and Financial Markets seventh edition - USA: Addison Wesley Longman Publishing, New York

10. Mishkin F.,(1996) Understanding Financial Crises: a Developing Countries Perspective - National Bureau of Economics Research

11. Балукоска Д., (2012) Влијанието на странските директни инвестиции врз економскиот раст и невработеноста на земјите во транзиција со осврт на Македонија, Универзитет „Американ Колеџ“ Скопје, Факултет за деловна економија и организациони науки, Скопје

12. Неновска Н., (2012) Макроекономски аспекти на странските директни инвестиции со посебен осврт на странските директни инвестиции во република Македонија, Универзитет „Св. Климент Охридски“ Битола - Економски факултет Прилеп

13. Македонија во бројки, Државен завод за статистика, Скопје, 2009

14. Странски директни инвестиции во Република Македонија 2003-2007, Државен завод за статистика, Република Македонија, Скопје, 2009 